\title{
南九十九里浜一宮海岸の \\ ヘッドランド周辺の地形特性 \\ BEACH CHANGES AROUND ARTIFICIAL HEADLANDS ON ICHINOMIYA COAST
}

\author{
宇多高明 1 熊田貴之 之 $^{2}$ 清水達也 $3 \cdot$ 冨澤和雄 4 - 川瀬 栄 5 - 今村康士 6 \\ Takaaki UDA, Takayuki KUMADA, Tatsuya SHIMIZU, Kazuo TOMIZAWA, \\ Sakae KAWASE and Yasushi IMAMURA
}

\footnotetext{
1正会員 工博 (財) 土木研究センター常務理事なぎさ総合研究室長兼日本大学客員教授理工学部 海洋建築工学科（干110-0016 東京都台東区台東1-6-4タカラビル）

2 正会員 博 (工) （財）土木研究センターなぎさ総合研究室 （テ110-0016 東京都台東区台東1-6-4タカラビル）

3 正会員 修 (工) （有）アイコムネット環境コンサルティング部

（テ135-0064 東京都江東区青海2-7-4-627）

4 千葉県長生地域整備センター建設課長（†297-0026 千葉県茂原市茂原1102-1）

5 千葉県長生地域整備センター建設課副主幹（干297-0026 千葉県茂原市茂原1102-1）

6 千葉県長生地域整備センター建設課主査（†297-0026 千葉県茂原市茂原1102-1）
}

\begin{abstract}
On the Ichinomiya coast located in the south part of Kujukuri Beach, ten artificial headlands have been constructed since 1983. By 2010, part of these headlands has been completed but the rest of them are still under construction. The shape of these headlands is classified into T-shaped and jetty-type, and characteristic beach changes occurred around these headlands depending on their shape. The shoreline changes around these artificial headlands were investigated on the basis of the aerial photographs, and typical shoreline changes were summarized.
\end{abstract}

Key Words : Artificial headland, Ichinomiya coast, shoreline changes

\section{1.はじめに}

九十九里浜は，房総半島東部において太平洋と接 し，北端の屏風ヶ浦から南端の太東崎まで伸びる長 さ約 $60 \mathrm{~km} の$ 砂浜海岸であり, 未固結の砂岩・泥岩で 構成された屏風ヶ浦と太東崎の海食崖からの崩落土 砂，および太東崎の南側に流入する夷隅川からの流 出土砂が沿岸漂砂によって浅い湾の中央部へと運び 込まれて堆積してできた海岸である。海浜は細砂か ら構成されているため緩勾配の海浜が形成されてい る.この海岸では1970年代以降進められた海食崖の 侵食防止工事, 九十九里浜の北端・南端に造られた 飯岡・太東漁港による沿岸漂砂の阻止などにより九 十九里浜への供給土砂量が激減した結果，近年では 弧状海岸線の両端部から中央部へと侵食が進んでき ている ${ }^{12)}$. このため九十九里浜南部に位置する一 宮海岸では，1983年より 10 基のヘッドランド

（HL）の建設が進められてきた。2010年現在これ らのHLは全てが完成形には至っておらず，縦堤が 伸ばされたのみのものもある。これらの様々な建設
段階にあるHLでは波の遮蔽効果がそれぞれ異なる ため, HL周辺の汀線形状もHL形状に応じた違いが 現れている。このようなHLの形状が周辺海浜へ及 ぼす影響を調べることはHLの設計における形状の 相違と海浜地形の関係を考察する上で有効な資料と なる，そこで，本研究では完成形に至るまで種々の 形状にあるHL周辺の汀線変化を空中写真に基づい て調べ, HLの縦堤, 横堤が延伸された場合の周辺 の汀線変化について分析した。同時に, $\mathrm{HL}$ 設置海 域では海底地形にも大きな変化が見られることから 2004年と2010年の深浅図の比較も併せて行った.

\section{2. 検討方法}

一宮海岸において現在まで建設が進められている 10 基のHLの配置を 2010 年の空中写真に示すと図-1 のようである。HLは一宮川河口から太東漁港まで 約 $7 \mathrm{~km}$ 区間に配置され，一宮川河口に隣接するのが 1 号堤，太東漁港近傍が 10 号堤である. HL $の$ 平均設 


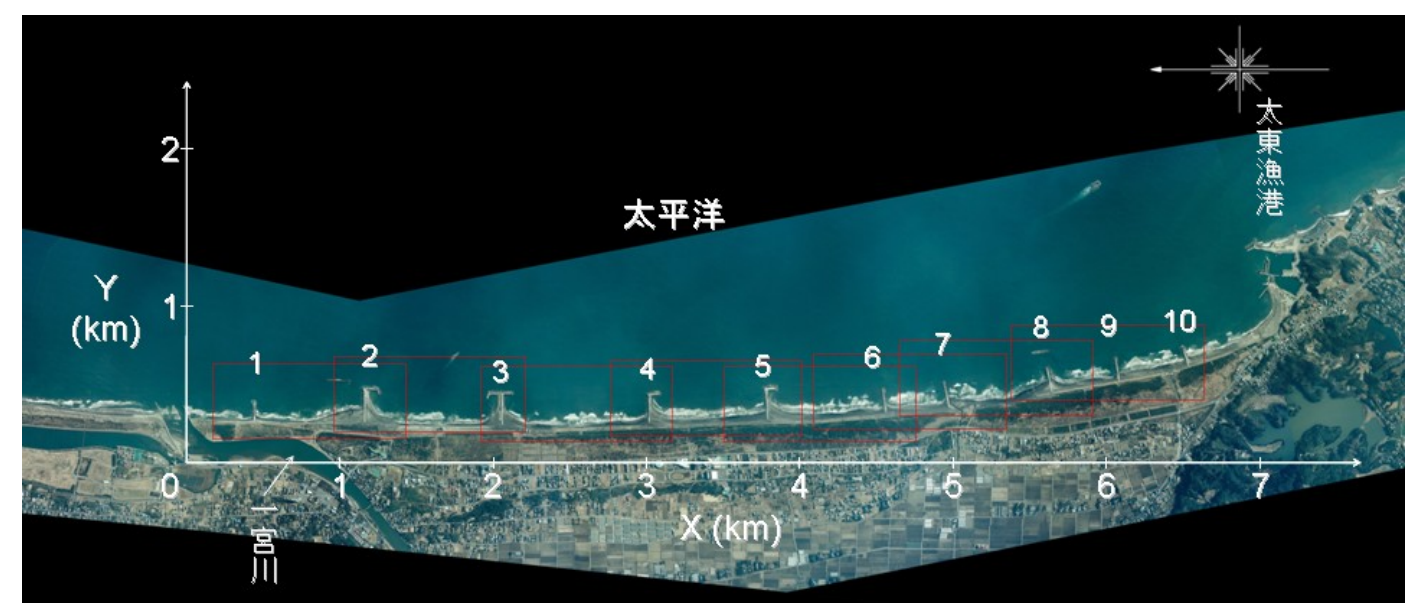

図-1 一宮海岸におけるへッドランドの配置

(a) 2004年



図-2 一宮海岸の2004年と2010年の深浅図

置間隔は680mであり，最小間隔は6，7号堤間の400m, 最長間隔は3，4号堤間の960mである。またHLは現 在もなお建設中のため, その形状は様々で 9,10 号 堤のように縦堤のみの場合と 2,3 号堤のように縦・ 横堤が完成したものもある。図-1のようにHLは沿 岸方向に配置されているので沿岸漂砂から見て同一 条件にはないが，HLの建設段階が互いに同じ状況 にあるもの，例えば両側とも縦堤のみ，片側にのみ 横堤がある場合，さらには両側のHLが完成形のも のなどに分類できる。 そこでHLの設置位置の相違
は無視した上HLが同一条件にあるものを集め，HL 形状の相違が汀線変化に及ぼす影響について検討し た. その場合の汀線変化量の算出では, HLがなく また侵食も起きていなかった1947年の汀線位置を基 準として変化量を算出した。

\section{3. 一宮海岸全域の深浅図の比較}

HL周辺の汀線形状特性を明らかにする前に, 全 
HLを含む広域の深浅図の比較を行い, HL周辺と HL 沖を含む区域の海底地形の特徵を調べた。一宮海岸 全体を包括した深浅測量は2004年になって初めて行 われ，その後現況の2010年に再度深浅測量が行われ た.ここではこれら2 時期の深浅図の比較を行った。 図-2には2004年と2010年の深浅図を示す。これらの 時期には既にHLの工事が進んでおり，少なくとも 縦堤はいずれのHLでも伸ばされていたが，2010年 までにいくつかのHLでは横堤も一部は伸ばされた。 これらの深浅図によれば，4号堤より北側では汀線 から-6mまでの等深線が互いに平行に延びているが， 4 号堤から太東漁港近傍では汀線と平行なのは-4mの 等深線であり，これらの水深を境に岸側と沖側の海 底勾配が急変し, 岸側の海底勾配と比較して沖合で は海底勾配が小さくなり, 緩勾配に変わる。これは 太東崎による波の遮蔽効果が現れ，太東崎に近づく と波による地形変化の限界水深が浅くなっているこ とに対応すると考えられる。また2004年と2010年い ずれの深浅図においても，2～5号堤ではHLの沖合 において等深線の蛇行が起きている. 宇多ら ${ }^{3)}$ は等 深線変化モデルを用いて動的平衡状態にある海岸に HLを設置した場合の沿岸漂砂の制御効果を予測し たが，HL沖ではHLによって沿岸漂砂が部分的に阻 止されると砂の一部がHL沖へと運ばれ, その砂が 下手側海浜で再び岸向きに移動し, その際等深線の 蛇行が起こる。このように, 一宮海岸のHL沖での 等深線の蛇行は, 宇多ら ${ }^{3)}$ が等深線変化モデルによ る検討で明らかにした現象と同じと考えられる。た だし宇多ら ${ }^{3)}$ は一方向の沿岸漂砂が卓越する場での 検討結果であったが，一宮海岸では波向が季節的に 大きく変動する特徵があるので, HL沖の等深線の 蛇行状況が南北対称形となっていると推定される. なお，銚子沖で観測されたデータ（2000～2008年) によれば，夏季のエネルギー平均波高は $1.5 \mathrm{~m}$


ギー平均波高は2.0m（T=7.9s），波向はN79 ${ }^{\circ} \mathrm{E}$ あ る.また，太東漁港近傍の6〜10号堤では縦堤のみ が伸ばされた状態にあるが，2004年も2010年とも等 深線の蛇行は顕著ではない。この付近は太東崎によ る波の遮蔽を受けるためHLの沖を回り込む沿岸漂 砂が小さくなっているためと考えられる。またこの ようなHL沖で等深線の蛇行現象が生じている点よ り，一宮海岸の既設の10基のHLでは沿岸漂砂の一 部はその先端を回り込むことができ, 静的平衡状態 の海浜とはなっていないと推察される.

\section{HL 形状に応じた汀線の変化}

\section{（1）縦堤のみの場合}

図-3，4には間隔 $400 \mathrm{~m} の 6 ， 7$ 号堤と間隔 $440 \mathrm{~m}$ の, 9 号堤周辺の空中写真と汀線変化を示す. 縦堤のみ 伸ばされた 6,7 号堤および9号堤ではHLの付け根付 近の汀線が直線状であり HLの軸線とほぼ直角に伸



図-3 6, 7号HL間の汀線変化

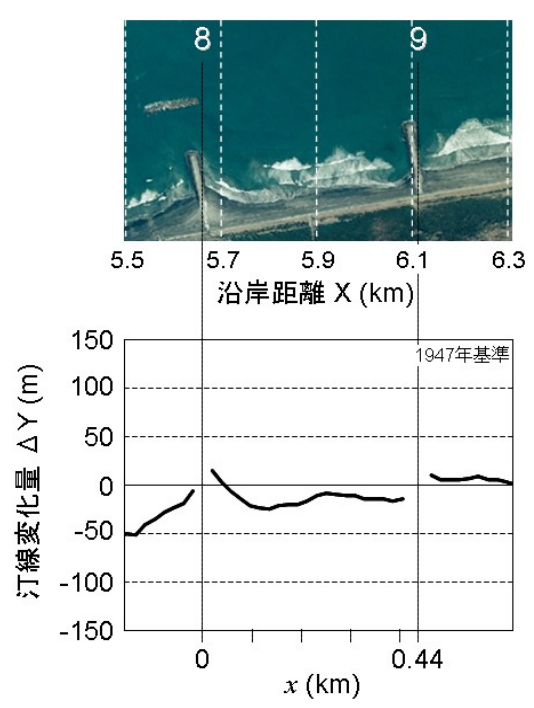

図-4 8，9号HL間の汀線変化

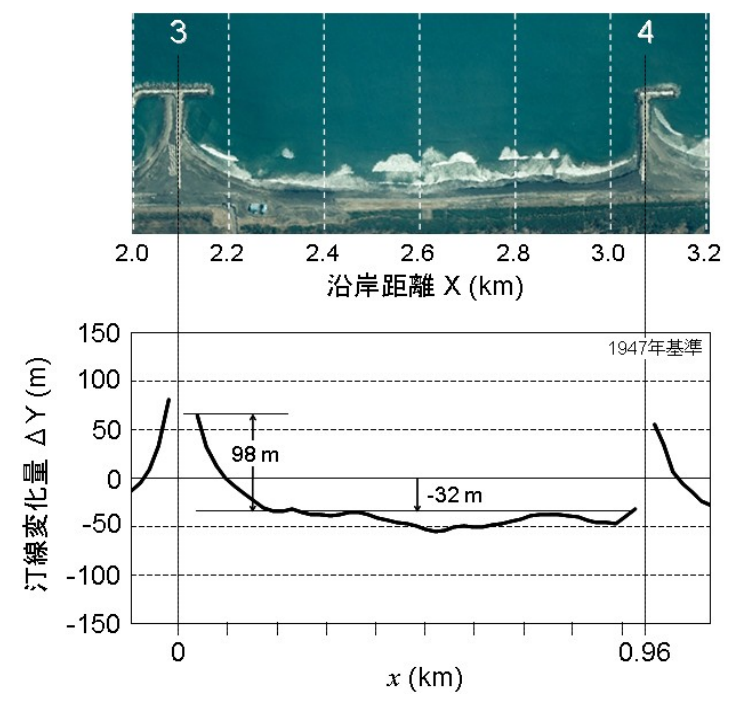

図-5 3，4号HL間の汀線変化 
びている.しかし8号堤では沖合に離岸堤が設置さ れており，それによる波の遮蔽効果のため8号堤の 縦堤の付け根付近で汀線が局所的に前進している. 各HL間の平均汀線位置を調べると， 8, 9号堤間で の-11mに対し6，7号堤間では-56mと，6，7号堤間で の汀線後退量が $45 \mathrm{~m}$ 大さいが, これはより広域的に 見た侵食・堆積域における各HLの相対位置に依存 すると考えられる。しかし縦堤を伸ばした場合， HLの付け根では汀線が立ち上がることなく直線的 に伸びることが分かる。

\section{（2）片側にのみ横堤がある場合}

このタイプには 3,4 号堤，4，5号堤，および5, 6 号堤が分類される。図-5，6，7には各ケースの汀 線変化を示す。図-5では，4号堤側では汀線はほぼ 直線状であるが，3，4号堤間の平均汀線位置（$32 \mathrm{~m}$ ）を基準とすると 3 号堤の付け根では98m汀線が 前進している。同様な特徵が4，5号堤の場合にも見 られ，4，5号堤間の平均汀線位置（-26m）を基準と して 4 号堤の付け根では $83 \mathrm{~m}$ の汀線前進が起きている. さらに5，6号堤の場合も同様であり，横堤を有する 5 号堤の付け根では5, 6 号堤間の平均汀線位置（50m）を基準として $88 \mathrm{~m} の$ 汀線前進が起きている．36 号堤の縦堤の長さは $200 \mathrm{~m}$, 横堤の長さは65mといず れも同一であるから，上記結果はHL構造が同一の 場合の結果と見なすことができる.これより長さ $200 \mathrm{~m}$ の縦堤に $65 \mathrm{~m}$ の横堤を伸ばした場合, 平均值と してHLの付け根では平均汀線位置より $90 \mathrm{~m} の$ 汀線前 進を見込むことができることが分かった．HL間の 砂の量がほぼ一定であればHLの横堤が延びればそ れに応じてHL間の中央部汀線が後退することにな る.

\section{（3）両側のHLが完成形}

両側のHLが完成しているのは2，3号HLである.

図-8は2，3号堤間における汀線変化を示す. 両側に 横堤が伸ばされたため両端部の汀線が急激に立ち上 がっている. 汀線前進量は平均汀線を基準として2 号堤では133m，3号堤では71mであって，対称形では なく北側の2号堤側の汀線前進量が大きい.また2号 HL背後の汀線前進量が大きいことと対応し, HL間 での汀線後退量は 2 号HLに近い $\mathrm{x}=0.3 \mathrm{~km}$ で最大後退 量-38mが現れており，北側の 2 号堤方向には急激に 変化する一方, 南側の3号HL方向には緩やかな後退 を示す。HL間の片側に横堤のみを伸ばした場合の 結果と考え合わせると，HL間の砂の量がほぼ一定 の条件では，HLの横堤を延ばすとそれに応じて HL 間の中央部汀線が後退することになる。すなわち横 堤の建設は, 波の遮蔽効果を通じてHL間の汀線曲 率を増大させる結果をもたらし, 横堤背後での過剰 な堆砂とHL間での汀線後退を招くことが明らかで ある。

\section{（4）片側に離岸堤がある場合}

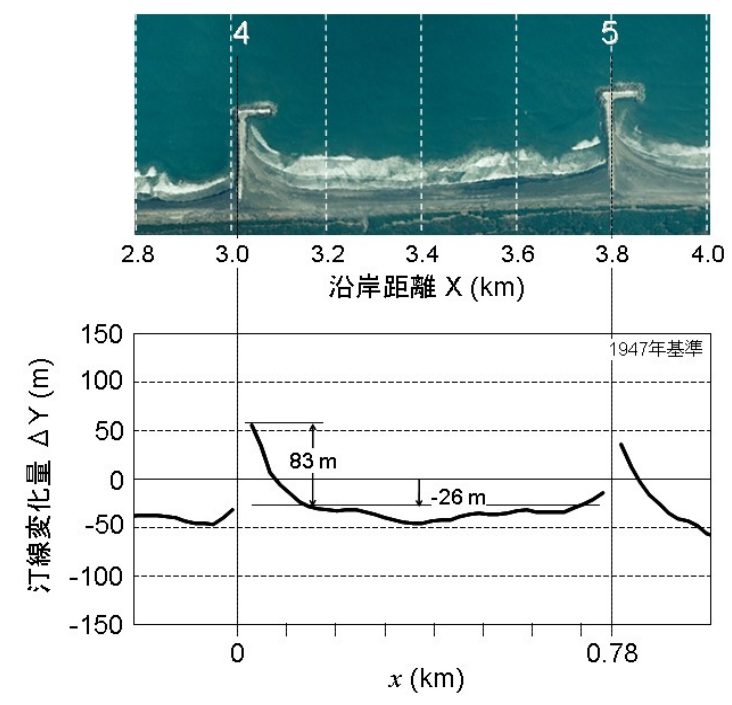

図-6 4, 5号HL間の汀線変化

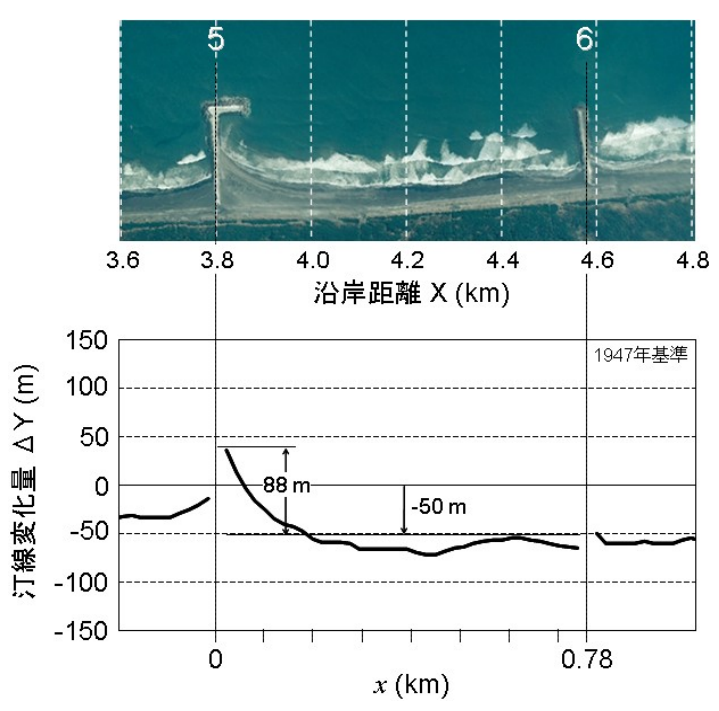

図-7 5，6号HL間の汀線変化

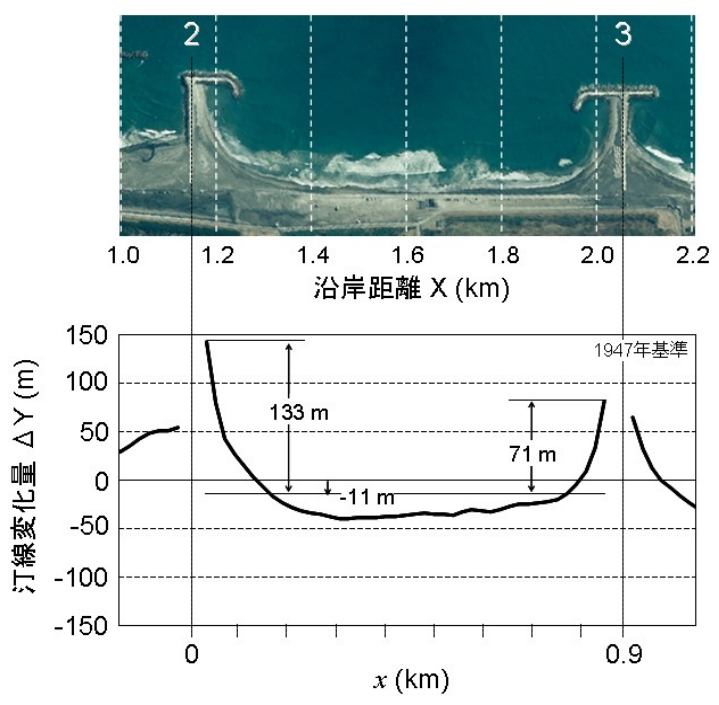

図-8 2，3号HL間の汀線変化 
片側に離岸堤が設置された場合としては，1，2号 堤間の2号堤近傍で離岸堤が設置された例（図-9） と8号堤の横堤が先行的に造られた場合（図-10）が ある. 図-9の場合には離岸堤の堤長が $160 \mathrm{~m}$ と長く, それが 2 号堤に接近して設置されたため $1 ， 2$ 号堤間 の中央南側の広い区域での汀線前進をもたらしてい る. しかし2号堤の南側の汀線がHLに向かって鋭く 立ちあがっているのに対し, 離岸堤背後では舌状砂 州が緩やかに発達するという違いがある８号堤の 横堤が先行的に造られた場合（図-10）には横堤と 縦堤の間にある $90 \mathrm{~m} の$ 隙間から波が侵入するため縦 堤と横堤が繋げられた場合より緩やかな形で砂の堆 積が起きている.

\section{HL 建設に伴う汀線の時間的変化}

2，3号堤の横堤は既に完成形を有する. これらの HLは1990年以降建設が進められ，2000年までは縦 堤が伸ばされたのみであったが，2005年までには横 堤も延ばされ 2010 年の完成形と同形となった。 した がって1990年と2000年の写真では縦堤のみ, 2005年 と2010年の写真では横堤も延ばされて完成形となっ た状態での汀線変化を調べることができる．4．で は最新の空中写真をもとに各建設段階にあるHLの 形状と周辺の汀線変化の関係について論じたが，同 様な特徵は 2,3 号堤の各建設段階における汀線変化 からも読み取れると考えられる。そしてHLの形状 変化に応じて汀線変化が起こるのであれば, 空間的 変化之時間的変化から得られた特徵は一致するはず である. そこで以下では $2 ， 3$ 号堤の建設に伴う周辺 の汀線の時間的変化過程を調べた. 図-11には4時期 の汀線変化を示す。いずれも自然状態にあった 1947 年の空中写真から定めた汀線を基準に汀線変化量を 求めた。図-11によれば，横堤がなかった1990年と 2000年にはHL間の汀線はほぼ直線状であったが, 横堤が伸び始めた2005年以降HL付け根部分での汀 線前進が始まった。これらの特徴は 4 .で得られた 結果とよく一致する。また2005年と2010年ではHL の形状は同一であり，ともにHLの付け根の汀線が 平均汀線より前進しているが，2010年では $\mathrm{x} \leqq$ $0.65 \mathrm{~km}$ で汀線が前進し, $\mathrm{x} \geqq 0.65 \mathrm{~km}$ では後退すると いうHL間での汀線の振動モードも重なっているこ とが分かる.

\section{6. まとめ}

\section{（1）ヘッドランド規模に応じた汀線前進・後退の 関係}

芹沢ら ${ }^{4)}$ は, Hsu・Evansの方法5) を応用し, ヘッ ドランドの横堤・縦堤の長さ, およびヘッドランド 間の海岸線の長さが与えられる条件のもとで, HL 背後の最大汀線前進量 $\Delta \mathrm{Y}_{\text {max }}$ と HL間の最大汀線後退

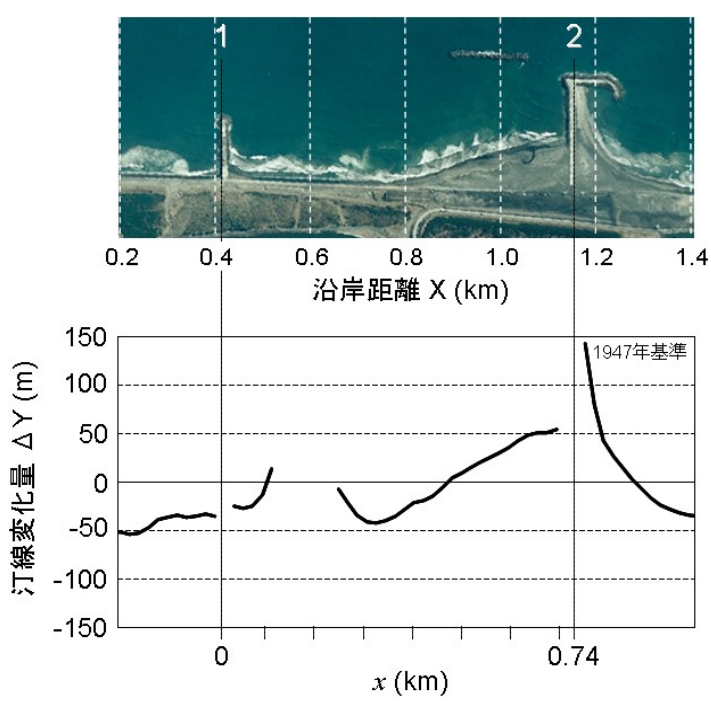

図-9 1，2号HL間の汀線変化

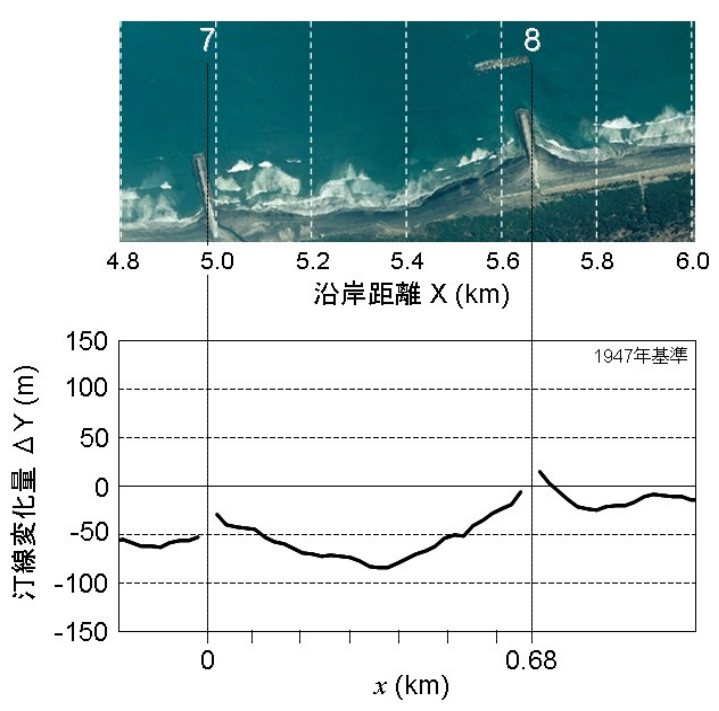

図-10 7, 8号HL間の汀線変化

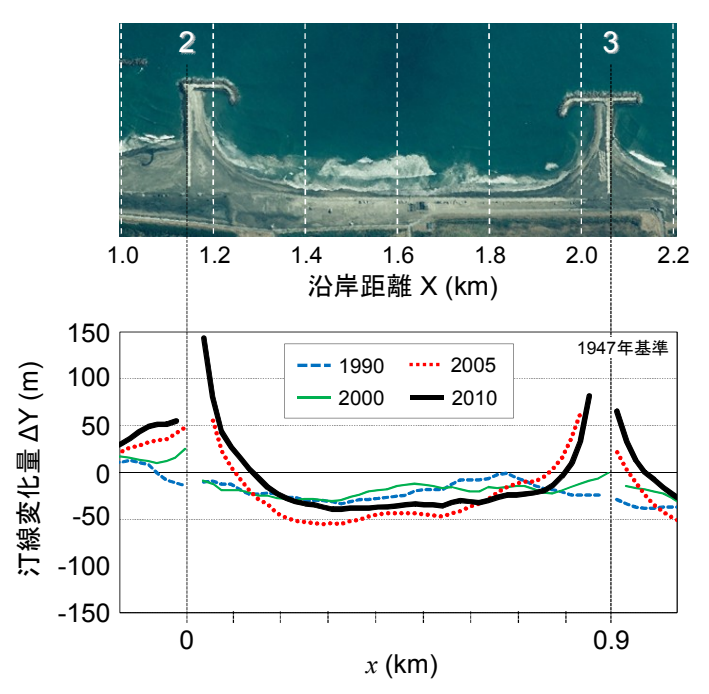

図-11 HL2，3号間における4時期の汀線比較 
量 $\Delta \mathrm{Y}_{\min }$ の算出法を示した. HLの横堤長を $\mathrm{a}$, 縦堤 の長さをb，ヘッドランド間の海岸線の長さをcとし， 片側にのみ横堤がある場合の $3 ， 4 ， 5$ 号HLを対象と すると，平均で $\mathrm{a}=65 \mathrm{~m}, \mathrm{~b}=250 \mathrm{~m}, \mathrm{c}=840 \mathrm{~m}$ であるから， $\mathrm{a} / \mathrm{b}=0.26, \mathrm{c} / \mathrm{b}=3.3 \fallingdotseq 3$ となる. そこで芹沢ら ${ }^{4)}$ の図一 10 より, $\Delta \mathrm{Y}_{\max } / \mathrm{b}=0.35, \Delta \mathrm{Y}_{\min } / \mathrm{b}=0.1$ と読み取れる bは65mなので, 最大汀線前進量は $\Delta \mathrm{Y}_{\max }=88 \mathrm{~m}$, 最大 汀線後退量は $\Delta \mathrm{Y}_{\min }=25 \mathrm{~m}$ となる。実測汀線前進量は $89 \mathrm{~m}$, 汀線後退量は $36 \mathrm{~m}$ となり, 汀線後退量は若干過 小評価ではあるものの，ほぼ妥当な結果が得られる。 芹沢 $5^{4)}$ の計算は，波向は直角入射，岸沖漂砂はな く, 計算領域内での土砂収支が成立するなど単純な 条件下での結果である。これに対し, 当海岸は波向 の季節変動に伴う汀線変動や, 波浪の強弱に伴う岸 沖漂砂の作用なども含まれているため, その分誤差 が生じうるが，そのような変動があっても芹沢ら ${ }^{4)}$ の方法である程度の予測が可能と考えられる.

\section{（2）海浜変形に対するエルゴード性}

4.で述べたHL周辺での汀線形状の特性は，ある 観測日（時間を固定して）に沿岸方向の場所を変え て撮影した空中写真から得られたものである。一方， 5.で述べたHL周辺での汀線形状の特性は, ある場 所で（場所を固定したとき）侵食が時間的に進んで いく場合の海浜変形のプロセスから得られたもので ある.両者の判読結果はともによく一致することが 明らかになった。このように，同じ時期に場所を変 えて見た各HL形状の違いによる汀線変化と, ある
同じ場所でHLの建設工事の進渉状況に応じた汀線 変化が同じ応答をしている。この概念（海浜変形に 対するエルゴード性 $\left.{ }^{1)}\right)$ が成立している点は，HL 建設に伴ってある時期までに測定された結果は，今 後HLの建設が進んだとき起こる現象を予め示して いることになる。例えば，縦堤を伸ばした後に横堤 を伸ばせば，HL背後の汀線は大きく前進するが， 同時にHL間の中央部では汀線が後退し, 波当りが 強まることなどが指摘できる。したがって実際の工 事においてはこれらの経験知を最大限利用すること が失敗を防止する上で大事である。

\section{参考文献}

1) 宇多高明: 日本の海岸侵食, 山海堂, p. 442, 1997.

2) 宇多高明, 古池 鋼, 三波俊郎, 芹沢真澄 : 海食崖に 続く堆積性弧状海岸線の形成とその変形予測, 地形, Vol. 30, pp. 331-348, 2009.

3) 宇多高明, 渡辺宗介, 古池 鋼, 星上幸良, 長山英 樹：ヘッドランドの規模の相違が海浜変形と通過沿岸 漂砂量に及ぼす影響, 海岸工学論文集, 第 55 巻, pp. 566-570, 2008.

4) 芹沢真澄, 宇多高明, 三波俊郎, 古池 剛, 神田康 嗣：修正 HSU モデルによるへッドランド周辺の最適 安定海浜形状の計算法, 海岸工学論文集, 第 43 巻, pp. 646-650, 1996.

5) Hsu, J. R. C. and C. Evans: Parabolic bay shapes and applications, Proc. Intn. Civ. Engrs., Part 2, 87, pp. 557-570, 1989. 